\title{
Laboratory Device to Assess the Effect of Mechanical Thinning of Flower Buds, Flowers and Fruitlets Related to Fruitlet Developing Stage
}

\author{
Angelo Romano ${ }^{1}$, Antonio Torregrosa ${ }^{2}$, , Sebastià Balasch ${ }^{3}\left(\mathbb{D}\right.$ and Coral Ortiz ${ }^{2, *(1)}$ \\ 1 Università degli Studi di Firenze, P.zza S. Marco 4, 50121 Firenze, Italy; angelo.romano@unifi.it \\ 2 Dpto. Ingeniería Rural y Agroalimentaria, Universitat Politècnica de València, Cno. Vera s/n, 46022 Valencia, \\ Spain; torregro@dmta.upv.es \\ 3 Dpto. de Estadística e Investigación Operativa aplicadas y Calidad Universitat Politècnica de València, \\ Cno. Vera s/n, 46022 Valencia, Spain; sbalasch@eio.upv.es \\ * Correspondence: cortiz@dmta.upv.es; Tel.: +34-963-877-295
}

Received: 24 September 2019; Accepted: 21 October 2019; Published: 23 October 2019

\begin{abstract}
Mandarin thinning is done by hand, increasing labor costs and raising total crop production costs. Mechanical thinning has been tested in peaches and other fruits. To achieve the maximum efficiency thinning has to be applied at a specific stage of vegetative development. In this research study, the mechanical thinning of 'Clemenrubi' mandarin branches during the different fruit development stages have been assessed using a vibratory laboratory device (amplitudes 0.015 and $0.030 \mathrm{~m}$ and frequencies 34.8 and $37.8 \mathrm{~Hz}$ ). Branches with flower buds, flowers, small green fruits, and medium green fruits were tested for 12 weeks, in two different seasons. It was possible to mechanically detach flower buds, flowers, and green fruits using different combinations of amplitudes and frequencies. Removal percentage decreased when increasing retention traction force, according to a logarithmic regression model. A significant increment in equatorial diameter and retention traction force was registered when the fruit setting was finishing, while mass had a similar development with a week delay. During fruit setting (weeks 5, 6, and 7) removal percentage was higher, while the retention force was very low. The first weeks just after the natural thinning could be considered the adequate time for a mechanical thinning operation.
\end{abstract}

Keywords: citrus fruit; mechanization; phenological stage; retention force

\section{Introduction}

Fruit thinning is the removal of certain flowers or fruitlets in order to improve fruit yield and quality and return bloom for the following year [1]. The final size of citrus fruits depends on the degree of competition among them, apart from other factors. Larger numbers of flowers and fruits increase competition that reduces total growth and the final size of the fruits [2].

There are three methods for thinning or crop load management: Hand, mechanical, and chemical. Hand thinning is not often applied as a commercial, cultural practice in citriculture due to the high cost [3]. However, mandarin hand thinning is usually done in some regions, like Valencia in Spain and the South Island in Japan.

Different studies confirmed the effect of chemical thinning agents (synthetic auxins) on mandarin thinning [4,5]. However, many chemicals are being released by the chemical companies [1] and other thinning methods could be assessed.

Mechanical thinning has been tested in peaches using inertial trunk shakers and electromagnetic shakers $[6,7]$. Besides, in stone fruits and pome fruits, flower and fruit thinning has been studied 
using drum shakers [8-10]. The studies proved that mechanical thinning saves time and reduces thinning cost.

In order to design a useful mechanical branch shaker thinning device for citrus fruits, defining the adequate vibration frequency and amplitude is necessary. However, during field shaking tests, many non-controlled factors are affecting the results.

Santos et al. [11] designed a laboratory electromagnetic shaker to determine adequate frequency and amplitude when detaching cherry coffee. A metallic device was fitted to the shaker to hold the coffee branches during the vibration tests.

Ortiz and Torregrosa [12] used a laboratory unidirectional vibratory device to vibrate mandarin branches in order to assess the adequate frequency, amplitude, and time for mechanical harvest, reducing the experimental field non-controlled factors.

Castro-Garcia et al. [13] assessed the frequency response of late-season 'Valencia' orange to selective harvesting by vibration using a laboratory unidirectional magnetic shaker. The excitation signal used was a random noise with frequencies from 0 to $60 \mathrm{~Hz}$, and a total duration of $60 \mathrm{~s}$. A set of five piezoelectric triaxial accelerometers was used to determine acceleration characteristics.

Citrus producers are usually not sure about the best thinning date and intensity since, for each variety, year, and development stage, the best option is different. Besides, to achieve the maximum efficiency of the crop management practices, they require to be applied at a specific stage of reproductive development [14]. In the citrus thinning operation, this factor is crucial.

The objective of the present study was to assess citrus mechanical thinning according to the fruit development stage by detaching flower buds, flowers, and green fruits using a laboratory device applying different combinations of amplitudes and frequencies.

\section{Materials and Methods}

The branches were selected and collected from an orchard of 'Clemenrubi' mandarin located in Sagunto (Valencia, Spain, Google maps coordinates: 39.645122, -0.303941). The trees were planted in a grid with an in-row spacing of 2 and $5.1 \mathrm{~m}$ between rows (980 trees/ha). Rows were on trapezoidal-shaped ridges, a tractor-mounted ridge machine were used to construct the berms commonly found in the Valencia region's citrus orchards, $0.5 \mathrm{~m}$ in height and $1.5 \mathrm{~m}$ wide at the top. Trees were of the variety Clemenrubi grafted onto Carrizo Citrange with an intermediate wood of 'Salustiano' orange. The age of the trees ranged from eight to ten years old from initial planting. Trunk height was $0.45 \pm 0.05 \mathrm{~m}$ and trunk diameter $0.11 \pm 0.01 \mathrm{~m}$. The trees had from three to five main branches. The canopy height above ground level was $2.2 \pm 0.2 \mathrm{~m}$ and the height from ground to canopy skirt was $0.9 \pm 0.2 \mathrm{~m}$. The canopy diameter perpendicular to row was $2.5 \pm 0.2 \mathrm{~m}$ and the canopy diameter parallel to row was $2.2 \pm 0.2 \mathrm{~m}$. The equivalent canopy volume was $6.8 \pm 1.3 \mathrm{~m}^{3}$.

During 2017 season, every week, during 12 consecutive weeks, 8 to 20 branches were selected and tested. Branches with flower buds, flowers, small green fruits, and medium green fruits, from phenological stage number 56 to phenological stage number 72 were tested, based on the $\mathrm{BBCH}$ scale [15], Table 1.

During 2018 season, every week, during eight consecutive weeks, 12 to 14 branches were selected and tested. In this second season small green fruits, medium green fruits, and high size green fruits (phenological stage number 72) were tested, stating the test later than the previous season (week 1 from 2018 season was related to week 10 from 2017 season). 
Table 1. Frequency, amplitude, phenological stage, and number of branches according to the week of the test.

\begin{tabular}{|c|c|c|c|c|c|c|c|c|c|c|c|}
\hline & \multirow[b]{2}{*}{ Week } & \multirow{2}{*}{$\begin{array}{l}\text { Frequency } \\
\quad(\mathrm{Hz})\end{array}$} & \multirow{2}{*}{$\underset{(\mathrm{mm})}{2017}$} & \multirow{2}{*}{$\begin{array}{c}\text { Phenological } \\
\text { Stage }\end{array}$} & \multicolumn{7}{|c|}{2018} \\
\hline & & & & & $\mathbf{N}^{o}$ & Date & Week & $\begin{array}{l}\text { Frequency } \\
\text { (Hz) }\end{array}$ & $\begin{array}{l}\text { Amplitude } \\
(\mathrm{mm})\end{array}$ & $\begin{array}{l}\text { Phenological } \\
\text { Stage }\end{array}$ & $\mathbf{N}^{\circ}$ \\
\hline 10-mar & 0 & $\begin{array}{l}7 / 10.5 / 13 / \\
13.7 / 34.8\end{array}$ & $15 / 30 / 120$ & $\begin{array}{c}56 \\
\text { Flower bud }\end{array}$ & 9 & & & & & & \\
\hline 23-mar & 1 & $\begin{array}{c}11.2 / 13.4 / \\
34.1 / 35.2 / 41\end{array}$ & $15 / 30$ & $\begin{array}{c}56 \\
\text { Flower bud }\end{array}$ & 9 & & & & & & \\
\hline 30-mar & 2 & $\begin{array}{l}23.2 / 34.8 / \\
37.8\end{array}$ & $15 / 30$ & $\begin{array}{c}59 \\
\text { Hollow flower bud }\end{array}$ & 9 & & & & & & \\
\hline 06-abr & 3 & $23.2 / 34.8$ & $15 / 30$ & $\begin{array}{c}65 \\
\text { Flower }\end{array}$ & 8 & & & & & & \\
\hline $12-a b r$ & 4 & 34.8 & $15 / 30$ & $\begin{array}{c}67 \\
\text { Withered flower }\end{array}$ & 8 & & & & & & \\
\hline 19-abr & 5 & $34.8 / 37.8$ & $15 / 30$ & $\begin{array}{c}71 \\
\text { Fruit setting }\end{array}$ & 11 & & & & & & \\
\hline 26-abr & 6 & $34.8 / 37.8$ & $15 / 30$ & $\begin{array}{l}72 \\
\text { Green fruit }\end{array}$ & 14 & & & & & & \\
\hline 04-may & 7 & $34.8 / 37.8$ & $15 / 30$ & $\begin{array}{c}72 \\
\text { Green fruit }\end{array}$ & 16 & & & & & & \\
\hline 10-may & 8 & $34.8 / 37.8$ & $15 / 30$ & $\begin{array}{c}72 \\
\text { Green fruit }\end{array}$ & 20 & & & & & & \\
\hline 17-may & 9 & $34.8 / 37.8$ & $15 / 30$ & $\begin{array}{c}72 \\
\text { Green fruit }\end{array}$ & 16 & & & & & & \\
\hline 24-may & 10 & $34.8 / 37.8$ & $15 / 30$ & $\begin{array}{c}72 \\
\text { Green fruit }\end{array}$ & 16 & 23-may & 1 & $18.9 / 37.8$ & 30 & $\begin{array}{l}72 \\
\text { Green fruit }\end{array}$ & 12 \\
\hline \multirow[t]{7}{*}{ 31-may } & 11 & $34.8 / 37.8$ & $15 / 30$ & $\begin{array}{c}72 \\
\text { Green fruit }\end{array}$ & 16 & 30-may & 2 & $18.9 / 37.8$ & 30 & $\begin{array}{c}72 \\
\text { Green fruit }\end{array}$ & 14 \\
\hline & & & & & & 06-jun & 3 & $18.9 / 37.8$ & 30 & $\begin{array}{c}72 \\
\text { Green fruit }\end{array}$ & 14 \\
\hline & & & & & & 13-jun & 4 & $18.9 / 37.8$ & 30 & $\begin{array}{l}72 \\
\text { Green fruit }\end{array}$ & 12 \\
\hline & & & & & & 21-jun & 5 & $18.9 / 37.8$ & 30 & $\begin{array}{l}72 \\
\text { Green fruit }\end{array}$ & 12 \\
\hline & & & & & & 27-jun & 6 & $18.9 / 37.8$ & 30 & $\begin{array}{l}72 \\
\text { Green fruit }\end{array}$ & 12 \\
\hline & & & & & & 04-jul & 7 & $18.9 / 37.8$ & 30 & $\begin{array}{l}72 \\
\text { Green fruit }\end{array}$ & 14 \\
\hline & & & & & & 11-jul & 8 & $18.9 / 37.8$ & 30 & $\begin{array}{c}72 \\
\text { Green fruit }\end{array}$ & 14 \\
\hline
\end{tabular}


A laboratory unidirectional vibratory device was constructed and used to vibrate the mandarin branches. It was based on the one developed by [12] and it consist in a connecting rod converted the rotational motion from an electric motor) into linear motion to vibrate the branch (Figure 1). A frequency converter was used to vary the vibration frequency from 4.5 to $40 \mathrm{~Hz}$. The vibration amplitude was modified from 0.015 to $0.18 \mathrm{~m}$ by placing the connecting rod in different disc holes (A). The branch was located in a vertical downward position (B).

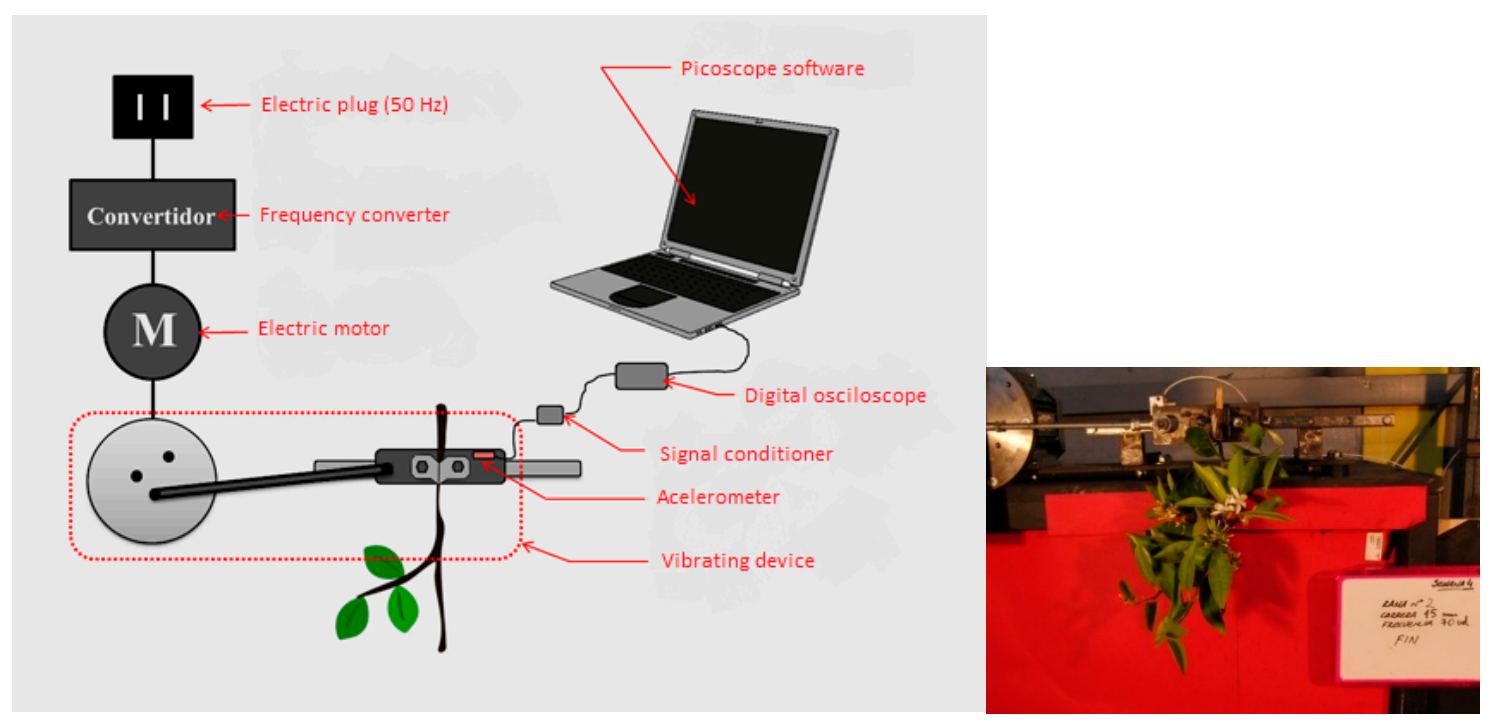

Figure 1. The laboratory unidirectional vibratory device.

Based on [16], the acceleration obtained from the combinations of amplitude and frequency, governed by Equation (1) was also considered.

$$
\mathrm{A}=\mathrm{A} \times \mathrm{f}^{2}
$$

where " $\mathrm{a}$ " is the acceleration, " $\mathrm{A}$ " is the amplitude, and " $\mathrm{f}$ " is the frequency.

Frequencies and accelerations applied were also calculated using a triaxial accelerometer (Kistler type 8763A500, range $\pm 500 \mathrm{G}$, sensitivity $10 \mathrm{mV} \mathrm{G}-1$, mass $3.3 \mathrm{~g}$, mini cube design $0.01 \mathrm{~m}$ length (Kistler Iberica, Barcelona, Spain).

In the first two weeks from 2017 season, a broad range of frequencies were tested in order to determine the most adequate conditions to detach flower buds. After the first two weeks, two amplitudes $(0.015$ and $0.030 \mathrm{~m})$ and three frequencies (34.8 and $37.8 \mathrm{~Hz}$ in 2017 and 18.9 and $37.8 \mathrm{~Hz}$ in 2018) were tested.

Physical characteristics, mass, maximum equatorial diameter, and retention traction force, of the flower buds, flowers, and green fruits were measured during the 12 weeks.

A high-speed color video camera Casio EXF1 (Casio Computer Co, Ltd., Tokio, Japan) was used to record the branch movements at 300 photographs per second.

A universal test machine (Ibertest, Daganzo, Madrid, Spain) was used to measure the retention traction force (Figure 2). The branch sample was located upside down grabbed by the traction clamp at the lower part (Figure 2A) and the flower bud, flower (Figure 2B), or green fruit (Figure 3) was grabbed by the gripper devise. 


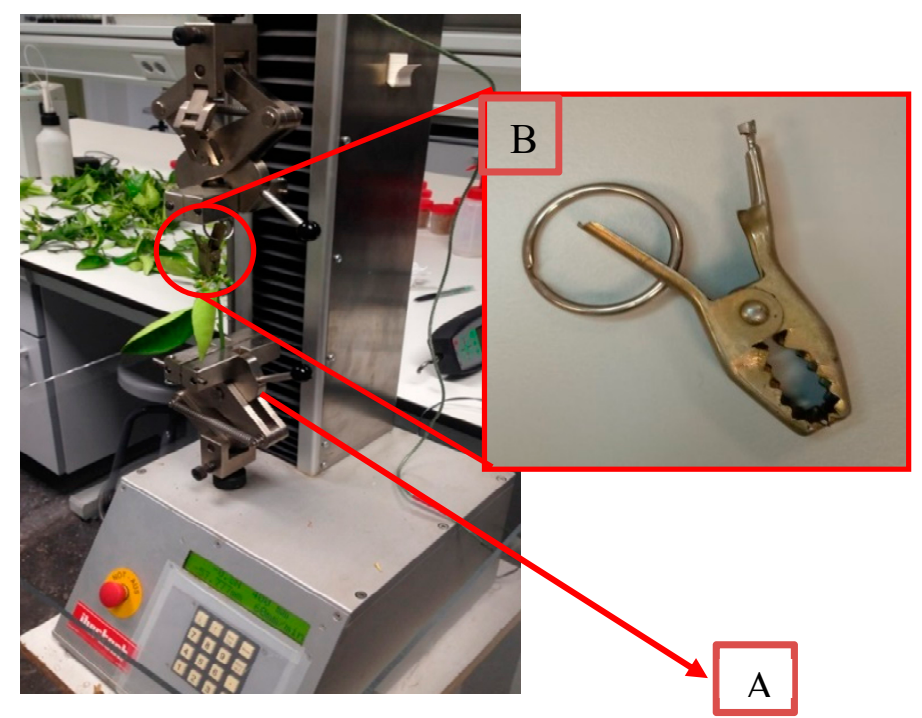

Figure 2. Universal test machine used for the traction retention force test and the gripper device for flower buds and flowers.

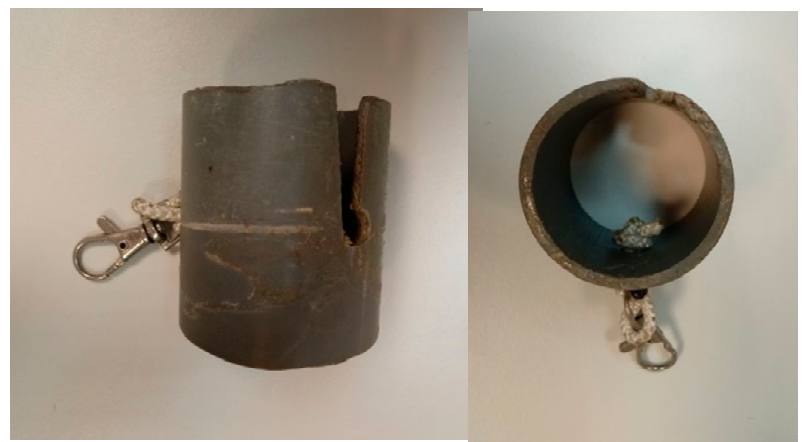

Figure 3. The gripper device used for green fruits.

Removal percentage during 10-second vibration of flower buds, flowers, small green fruits, and medium green fruits were measured.

\section{Results}

\subsection{Physical Parameters Development According to Time}

When studying mass, diameter and removal traction force from 2017 and 2018 seasons, it was confirmed that green fruits (phenological stage 72) from the first week in 2018 did not correspond to those from week 10 from 2018. Green fruits from week 1 of 2018 season were similar to those from week 6/7, from 2017 season. This fact could be due to the differences in the two seasons and also to the different procedure followed to choose the branches.

Diameter, mass, and retention force development during the phenological stage development are shown in Figure 4.

Until week 3 (flower buds, and withered flower buds, phenological stages 56-59), the diameter of the flower buds and flowers was very low. From week 4 to week 8 , the diameters were lower than $4.2 \mathrm{~mm}$. This initial phase of the fruitlet growth was related to the increase in the pericarp thickness several weeks after the petal fall [17]. From week 8 , a high increase of the green fruit diameter was registered. Regarding the second phase of the fruitlet growth with a cell enlargement, there was vacuolization of the juice sacs and an increase in the size of the locules. 


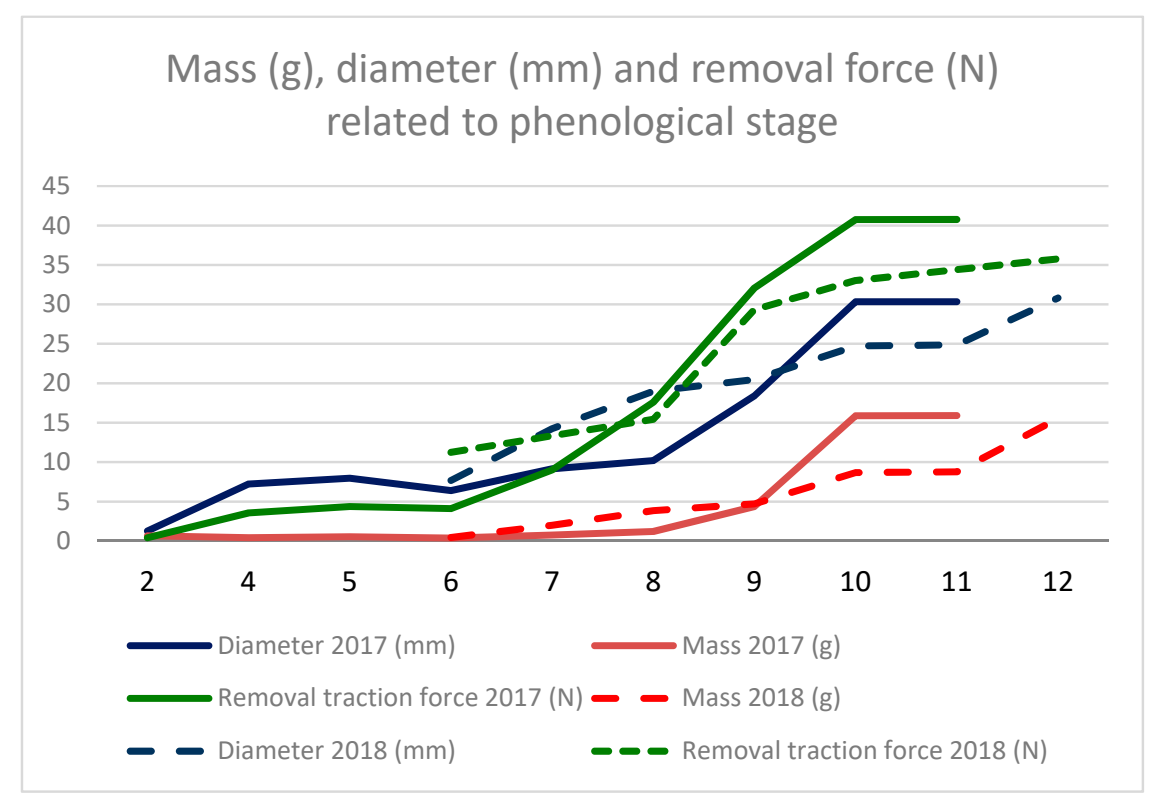

Figure 4. Mass $(\mathrm{g})$, equatorial diameter $(\mathrm{mm})$ and retention removal force $(\mathrm{N})$ of the flower buds, flowers and green fruits according to the weeks in 2017 and 2018 seasons.

Regarding mass, it was lower than $1.2 \mathrm{~g}$ until week 8 , when a drastic change in the mass of the green fruits was produced.

Retention force evolution was very similar to mass. However, retention force was one week ahead of the mass, starting to drastically increment in the seventh week.

The number of flower buds, flowers, or fruitlets registered along the weeks reduced drastically after week 7, which was related to the natural thinning of the tree in 2017 season (Figure 5).

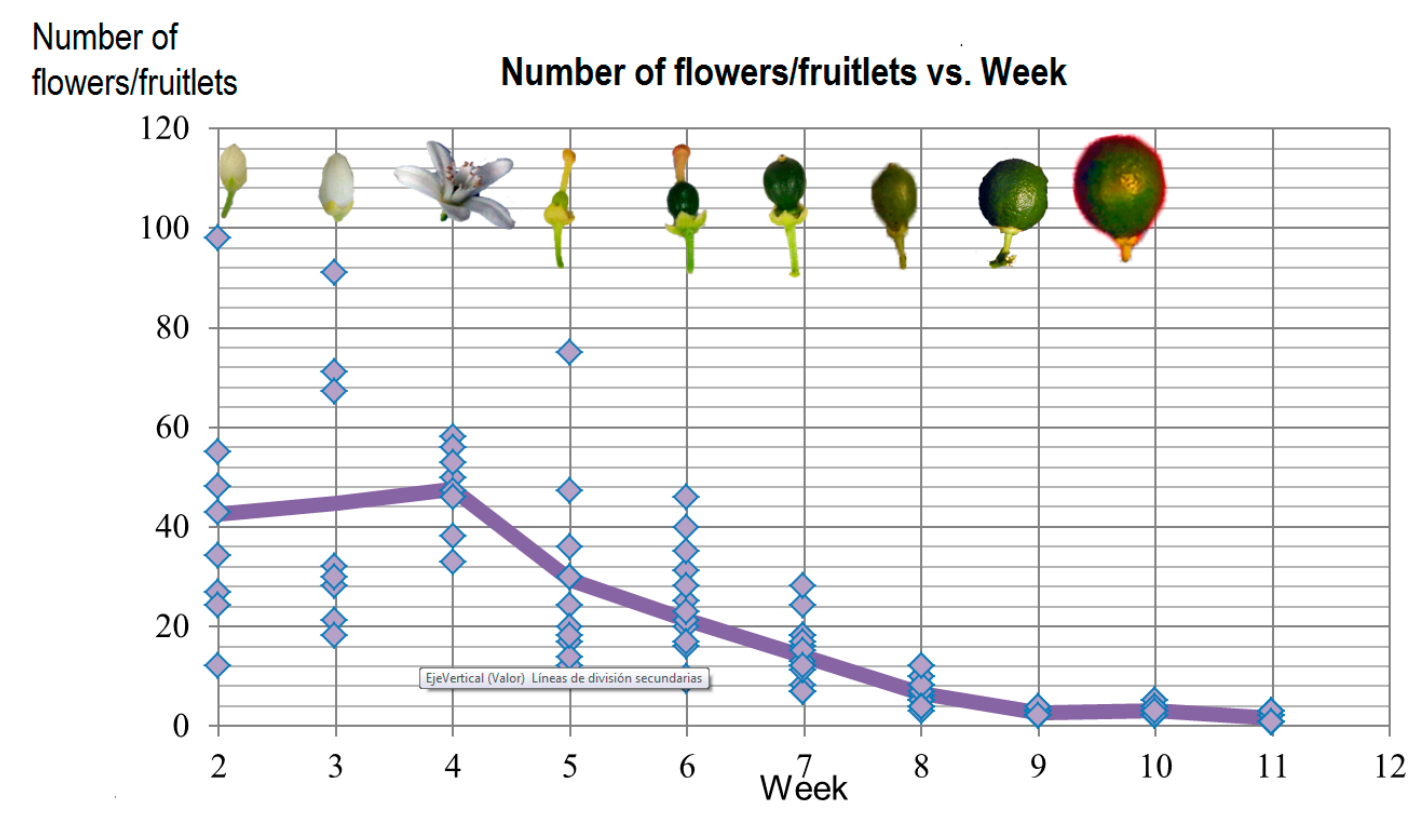

Figure 5. Number of flower buds, flowers, or fruits according to the week.

\subsection{Removal Percentage According to Vibration Amplitude and Frequency}

Both vibrating parameters, amplitude and frequency and development time (week), significantly affected the removal percentage, Table 2 . 
Table 2. Variance analysis of the effect of the factor frequency, week, and amplitude on the variable removal percentage for 2017 and 2018 seasons.

\begin{tabular}{cccccc}
\hline Source & Square Sum & $\begin{array}{c}2017 \text { Season } \\
\mathrm{df}\end{array}$ & Average Square & F-value & P-value \\
\hline Principal Effect & & & & & \\
A: Frequency & 3843.15 & 1 & 2843.15 & 4.69 & 0.0322 \\
B: Week & $20,297.2$ & 9 & $50,585.4$ & 61.77 & 0.0057 \\
C: Amplitude & $50,585.4$ & 1 & 818.967 & & \\
Residues & 100,733 & 123 & & & \\
Total (Corrected) & 171,463 & 134 & & & \\
\hline Source & Square Sum & df & Average Square & F-value & P-value \\
Principal Effect & & & & & \\
A: Frequency & $48,810.0$ & 1 & $48,810.0$ & 113.11 & 0.0000 \\
B: Week & 9798.8 & 6 & 1633.13 & 3.78 & 0.0022 \\
Residues & $35,384.3$ & 82 & 431.516 & & \\
Total (Corrected) & $93,993.1$ & 89 & & & \\
\hline
\end{tabular}

According to Equation (1), the acceleration applying $37.8 \mathrm{~Hz}$ is only 1.2 times higher than the acceleration applying $34.8 \mathrm{~Hz}$. Despite the small difference between the two frequencies studied in 2017, the average removal percentage when vibrating with a $34.8 \mathrm{~Hz}$ frequency was around $33 \%$ compared to nearly $48 \%$ when vibrating with $37.8 \mathrm{~Hz}$ frequency. In 2018 , the differences in removal percentage between the two vibrating frequencies were very significant, as it was expected taking into account that the acceleration applying $37.8 \mathrm{~Hz}$ is four times higher than the acceleration applying $18.9 \mathrm{~Hz}$. The removal percentage was $11.1 \%$ for $18.9 \mathrm{~Hz}$ and $57.21 \%$ for $37.8 \mathrm{~Hz}$, with a $30 \mathrm{~mm}$ amplitude in both cases.

The removal percentage when using the $30 \mathrm{~mm}$ amplitude was always higher than the removal percentage when using $15 \mathrm{~mm}$ amplitude, while the acceleration was twice higher with $30 \mathrm{~mm}$ than with $15 \mathrm{~mm}$ (Figure 6). When using a $30 \mathrm{~mm}$ amplitude, the removal percentages were always very high, more than $30 \%$. It could be more interesting using the $15 \mathrm{~m}$ frequency. However, it is important to remark that the removal percentages were considered when vibrating for 10 seconds. A sorter vibration with $30 \mathrm{~mm}$ could be acceptable.



Figure 6. Removal percentage (\%) development according to amplitude (15 mm, $30 \mathrm{~mm}$ and total) and related to retention traction force $(\mathrm{N})$ for 2017 season. 
During weeks 2 and 3, phenological stages 56, 59, and 65, the removal percentages increased, making it possible to remove flower buds, hollow flower buds, and small flowers with the frequencies and amplitudes studied.

Removal percentages in week 4 (withered flower stage, phenological stage 67) were reduced. This could be due to the increment of the air resistance when vibrating, related to the opening of the petals.

In 2017, the highest removal percentages were found during weeks 5, 6 and 7, when the retention force was very low (Figure 6). This tendency was also confirmed in 2018 with a brief delay This period corresponds to the natural thinning. After these weeks, the amount of fruits was naturally drastically reduced (Figure 5) and the retention force increased and the removal percentage decreased. The first weeks just after the natural thinning could be considered adequate for mechanical thinning.

Considering only the green fruits, a logarithmic regression model was found between the removal percentage of the green fruits $(\%)$ and the retention traction force $(\mathrm{N})$, with $87.6 \%$ R2 (Figure 7), following Equation (2).

$$
\text { Removal percentage }(\%)=67.5-16.1 \ln F t
$$

$\%$ derribo $=67,5111-16,0882 * \ln (\mathrm{Ft})$

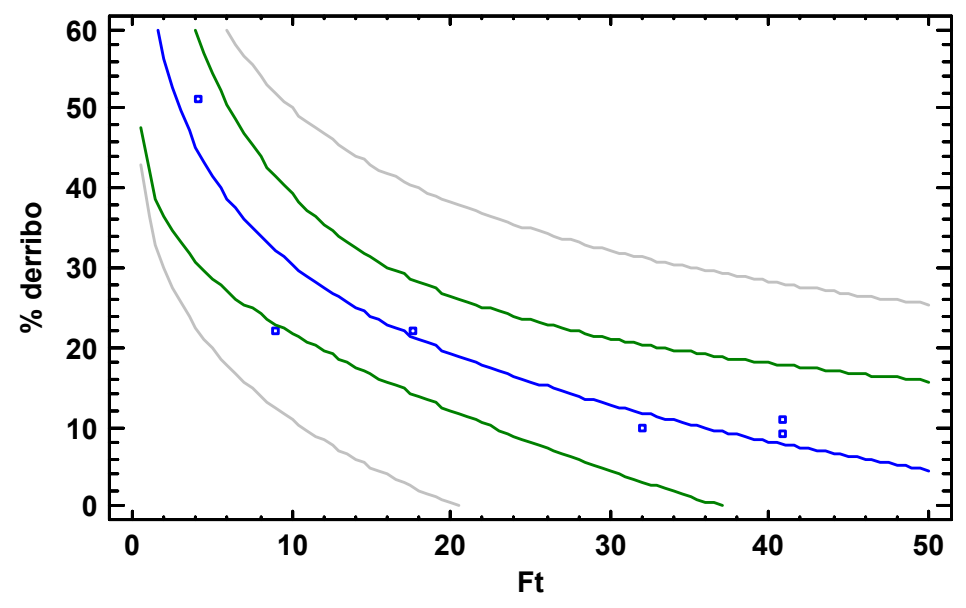

Figure 7. Logarithmic regression model between the removal percentage of the green fruits (\%) and the retention removal force $(\mathrm{Ft}, \mathrm{N})$.

\section{Conclusions}

It is possible to detach flower buds, flowers, and green fruits using different combinations of amplitudes (30 or $15 \mathrm{~mm}$ ) and frequencies (34.8 and 37.8), under the laboratory conditions studied.

Amplitude, frequency, and phenological stage significantly affect removal percentage.

The removal percentage when using the $30 \mathrm{~mm}$ amplitude was always higher (more than $30 \%$ ) than the removal percentage when using $15 \mathrm{~mm}$ amplitude, with frequencies of 34.8 and $37.8 \mathrm{~Hz}$. The average removal percentage when vibrating with a $34.8 \mathrm{~Hz}$ frequency was around $33 \%$ compared to nearly $48 \%$ when vibrating with $37.8 \mathrm{~Hz}$ frequency.

Equatorial diameter and retention traction force have very low values until the sixth/seventh week (phenological stage 72), when the fruit setting is finishing, and a significant change of slope increment is registered. Mass has a similar development with a week delay.

Removal percentage decreases when increasing retention traction force, according to a logarithmic regression model. 
Removal percentage is higher during weeks 5, 6, and 7 during fruit setting, when the retention force is very low coinciding with the tree natural thinning. The first weeks just after the natural thinning could be considered the adequate time for a mechanical thinning operation.

Author Contributions: Data curation, A.R. and C.O.; funding acquisition, A.R.; investigation, A.R., A.T., S.B. and C.O.; methodology, A.R., A.T., S.B. and C.O.; supervision, C.O.; visualization, S.B.; writing-original draft, A.T. and C.O.; writing-review \& editing, C.O.

Funding: The present study has been funded by Instituto Nacional de Investigación y Tecnología Agraria y Alimentaria (INIA) and FEDER (Project RTA2014-00025-C05-02).

Acknowledgments: The company Fontestat provided the experimental fields. Special thanks go to technician Federico Izquierdo and to the UPV technicians Montano Pérez and Juan José Peña. We would like to thank Clare Treleaven for her English Language revision of the manuscript.

Conflicts of Interest: The authors declare no conflicts of interest.

\section{References}

1. Ouma, G. Fruit thinning with specific reference to citrus species: A review. Agric. Biol. J. N. Am. 2012, 3, 175-191. [CrossRef]

2. Mesejo, C.; Martínez-Fuentes, A.; Juan, M.; Almela, V.; Agustí, M. Vascular tissues development of citrus fruits peduncle is promoted by synthetic auxins. Plant Growth Regul. 2003, 39, 131-135. [CrossRef]

3. Stander, O.P.J.; Cronjé, P.J.R. Reviewing the Commercial Potential of Hand Thinning in Citrus with a Cost-benefit Analysis of Summer Hand Thinning of 'Nadorcott' Mandarin. HortTechnology 2016, 6, $206-212$. [CrossRef]

4. Mesejo, C.; Rosito, S.; Reig, C.; Martinez-Fuentes, A.; Agustí, M. Synthetic Auxin 3,5,6-TPA Provokes Citrus clementina (Hort. ex Tan) Fruitlet Abscission by Reducing Photosynthate Availability. J. Plant Growth Regul. 2012, 31, 186-194. [CrossRef]

5. Gonzatto, M.P.; Böettcher, G.N.; Schneider, L.A.; Silveira, J.C.; Petry, H.B.; Pedroso de Oliveira, R.; Schwarz, S.F. 3,5,6-trichloro-2-pyridinyloxyacetic acid as effective thinning agent for fruit of 'Montenegrina' mandarin. C. R. Santa Maria 2016, 46, 2078-2083. [CrossRef]

6. Powell, A.A.; Hancock, B.G.; Puls, E.E.; Helmers, S.G., Jr.; Brown, M.H., Jr. Utilizing mechanical fruit thinning in commercial peach orchards. HortScience. 1975, 10, 142.

7. Rosa, U.A.; Cheetancheri, K.G.; Gliever, C.J.; Lee, S.H.; Thompson, J.; Slaughter, D.C. An electro-mechanical limb shaker for fruit thinning. Comput. Electron. Agric. 2008, 61, 213-221. [CrossRef]

8. Schupp, J.R.; Baugher, T.A.; Miller, S.S.; Harsh, R.M.; Lesser, K.M. Mechanical Thinning of Peach and Apple Trees Reduces Labor Input and Increases Fruit Size. HortTechnology 2008, 18, 660-670. [CrossRef]

9. Miller, S.S.; Schupp, J.R.; Baugher, T.A.; Wolford, S.D. Performance of Mechanical Thinners for Bloom or Green Fruit Thinning in Peaches. HortScience 2011, 46, 43-51. [CrossRef]

10. Seehuber, C.; Damerow, L.; Blanke, M.M. Concepts of selective mechanical thinning in fruit tree crops. Acta Horticulturae 2013, 998, 77-83. [CrossRef]

11. Santos, F.L.; Marçal de Queiroz, D.; Carvalho-Pinto, F.A.; Terra-Santos, N. Analysis of the coffee harvesting process using an electromagnetic shaker. Acta Sci. Agron. 2010, 32, 373-378. [CrossRef]

12. Ortiz, C.; Torregrosa, T. Determining adequate vibration frequency, amplitude, and time for mechanical harvesting of fresh mandarins. Trans. ASABE 2013, 56, 15-22. [CrossRef]

13. Castro-Garcia, S.; Blanco-Roldán, G.L.; Ferguson, L.; González-Sánchez, E.J.; Gil-Ribes, J.A. Frequency response of late-season 'Valencia' orange to selective harvesting by vibration for juice industry. Biosyst. Eng. 2017, 155, 77-83. [CrossRef]

14. Albrigo, L.G.; Valiente, J.I.; Beck, H.W. Flowering expert system development for a phenology based citrus decision support system. ISHS Acta Hortic. 584 VI Int. Symp. Comput. Model. Fruit Res. Orchard Manag. 2001, 247-254. [CrossRef]

15. Agustí, M.; Zaragoza, S.; Bleiholder, H.; Buhr, L.; Hack, H.; Klose, R.; Staus, R. Adaptation of the BBCH scale for the description of Citrus fruits' phenological stages. Fruit 1997, 52, 287-295. 
16. Solomakhin, A.A.; Blanke, M.M. Mechanical flower thinning improves the fruit quality of apples. J. Sci. Food Agric. 2009, 90, 735-741. [CrossRef] [PubMed]

17. Guardiola, J.L.; García-Luis, A. Increasing fruit size in Citrus. Thinning and stimulation of fruit growth. Plant Growth Regul. 2000, 31, 121-132. [CrossRef] 